\title{
Changes in soil microbial diversity and control of Fusarium oxysporum in continuous cropping cucumber greenhouses following biofumigation
}

\author{
Lingbo Meng' ${ }^{1}$, Xiaotong $\mathrm{Yao}^{2}$, Zichao Yang ${ }^{2}$, Runzhi Zhang ${ }^{2}$, Chunyi Zhang ${ }^{2}$, Xuerong Wang ${ }^{2}$, Ning $\mathrm{Xu}^{2}$, \\ Shumin $\mathrm{Li}^{2 *}$, Tongtong Liu², Chengyu Zheng², \\ ${ }^{1}$ School of Food Engineering, Harbin University, Harbin, China, ${ }^{2}$ Resource and Environmental College, Northeast Agricultural University, \\ Harbin, China
}

\section{A B S T R A C T}

\begin{abstract}
Soil biofumigation with Brassia plant parts has been demonstrated to suppress soil-borne pathogens. This effect has been attributed to the bactericidal effect of their glucosinolate degradation products. However, little is known regarding the effect of biofumigation on the microbial community structure and control of Fusarium oxysporum in continuous cropping cucumber systems. Field and pot experiments were performed to study the effect of biofumigation with brassica crops of different glucosinolate contents on the microbial diversity and control of Fusarium oxysporum during the cucumber growth period in a continuous cropping culture system. Samples collected from biofumigation and control treatments differed in the number of soil bacterial bands observed by denaturing gradient gel electrophoresis (DGGE) profiling, suggesting that biofumigation changed the soil microbial diversity. Compared with control and chemically-fumigated (HY) soils, the biofumigated soil exhibited significantly higher Shannon-Weaver diversity indices for bacteria and fungi. Cluster analysis and principal component analysis revealed that soil bacteria communities were different in the hymexazol (HY)-treated soils compared with the communities before biofumigation (BB) and those in the no fumigation (CK) groups. This was true for the mustard containing high glucosinolates (MHG), mustard containing low glucosinates (MLG), mustard (MU), and turnip (TU) groups. Pot experiments demonstrated that the amounts of Fusarium oxysporum in MHG- and HY-treated soils were significantly lower than those in other biofumigation treatments. These results demonstrate the potential utility of Brassica crops in the control of Fusarium wilt in continuous cucumber cropping systems, and the control effect of MGH was the best compared with other treatments, which could effectively reduce Fusarium oxysporum in soil by more than $60 \%$.
\end{abstract}

Keywords: Biofumigation; PCR-DGGE; Soil microbial community; Fusarium oxysporum; Cucumber

\section{INTRODUCTION}

The cucumber is an important species cultivated in greenhouses in Heilongjiang, China. Owing to the limited availability of agricultural land and high market demand, continuous cucumber cropping has been widely adopted. Continuous cropping affects cucumber yield and quality. Soil-borne disease pathogens and secondary salinization are commonly observed in continuously cropped soil.

Currently, the use of methyl bromide for soil fumigation has been banned because repetitive chemical fumigation raises air pollution concerns. Methyl bromide has been known to contribute to the depletion of the atmospheric ozone layer, thus increasing UV-B irradiation and the risks of skin cancer and cataract in humans (Loenen et al., 2003). Because fumigants are volatile, atmospheric emission is one of the main pathways for offsite transport (Wang et al., 2009). The recent increasing demand for environment-friendly fumigants has led to a renewed interest in finding alternative methods for controlling soil-borne pathogens(Giotis et al., 2009).

Many soil treatments have been suggested as alternatives to chemical soil disinfection (Noble and Coventry, 2005; Van Bruggen et al., 2015). Biofumigation is the suppression of soil-borne pests and pathogens resulting from biocidal compounds released from brassicaceous crops following the hydrolysis of glucosinolates (GSLs) present in their tissues. The disease-suppressive effect of brassica green manures, 
crop residues, and/or processing waste incorporated into soil has been attributed to the glucosinolate content (Kirkegaard, 2006). In a pioneering work on biofumigation, brassica tissue incorporated into wheat fields reduced the abundance of wheat take-all pathogens (Gaeumannomyces graminis var. tritici) (Angus et al., 1994). This soil treatment increased the soil organic matter content and enhanced soil fertility and has been extensively studied in recent years ( $\mathrm{Li}$ et al., 2007). Two plants, including the mustard and turnips, which are high in glucosinolate, also inhibit the growth of weeds (Vaughn et al., 2005).

A previous study reported that the main biocidal substances, isothiocyanates, released into brassica plantfumigated soil as a result of GSL degradation, have similar effects as that of the chemical fumigants Metham sodium (MS) and Dazomet (Sarwar and Kirkegaard, 1998). The inhibitory effects of biofumigation on fungal (ascomycetes) and bacterial (ammonia-oxidizing bacteria) guilds are superior to that of Metham sodium (Omirou et al., 2011). The biofumigant effect of pepper crop residues could effectively suppress the populations of Meloidogyne incognita in laboratory conditions (Buena et al., 2007). In a field experiment, three different green manures (Austrian winter pea, Pisum sativum L.; broccoli Brassica oleracea L.; or Sudan grass, Sorghum vulgare) were incorporated into soil at three different rates, which resulted in similar suppressive effects on Verticillium dablia (Ochiai et al., 2008). Fusarium wilt on flax was reduced to a greater extent by complex than by simple amendments (Senechkin et al., 2014), and the suppression was related to microbial activity. Brassica species are increasingly being used as cover crops for the suppression of soil-borne diseases in potato cropping systems (Snapp et al., 2007). Additionally, many studies have reported that fresh brassica tissues significantly reduce the severity of soil-borne diseases (Giotis et al., 2009).

The density of Fusarium spp. and the abundance of Trichoderma increased significantly in soil after biofumigation with the seed meals of B. juncea and B. carinata (Paudel et al., 2016). Additionally, the inhibitory effect of biofumigation on Fusarium oxysporum f. sp. lycopersici is superior to those of of soil solarization and soil disinfection methods (Li et al., 2006). Several plants, especially mustard and turnip, have been extensively studied as green manure crops (when grown or incorporated in the soil) because of their ability to suppress weeds or soilborne pests (Vaughn et al., 2005).

Due to the sensitivity of soil microbes to isothiocyanates, these compounds could significantly change the structure of the soil microbial community. The main GSL found in Turnip is 2-hydroxy-3-butenyl glucosinolate. Although the hydrolysis products of this compound exert little inhibitory effect on Rhizoctonia or Pratylenchus, these products increase the abundance of Streptomyces spp. and a nitric oxide synthase-containing holophytic Nitrobacterium in the soil (Cohen et al., 2005).

Fusarium oxysporum is the main disease that affects cucumber yield and quality in continuously cropped cucumber soil. The changes in soil microbial diversity resulting from biofumigation in continuous cucumber soil are not clear. Denaturing gradient gel electrophoresis (PCR-DGGE) of PCR-amplified 16S rRNA gene fragments has been widely used to analyze the composition and diversity of microbial communities present in natural environments (Omirou et al., 2011; van Diepeningen et al., 2005). In the present work, brassica crops with different GSL contents were used to fumigate continuously cropped cucumber soil. The objectives of the present work were (1) to use the PCR-DGGE method to evaluate microbial community structures and their diversity in continuously cropped cucumber soil treated with different brassica crops for biofumigation and (2) to determine the effect of biofumigation materials on Fusarium wilt in soil continuously cropped with cucumber.

\section{MATERIALS AND METHODS}

\section{Soil microbial diversity and glucosinolate concentration analysis Experiment design}

This experiment was conducted at the horticultural experimental station of Northeast Agricultural University, China $\left(45^{\circ} 45^{\prime} \mathrm{N}, 126^{\circ} 38^{\prime} \mathrm{E}\right)$. The soil used in this experiment was used for cropping cucumber soil for ten years and was infected with Fusarium oxysporum $f$. sp. cucumerinum. Before the soil was biofumigated, properties of soil at depths from 0 to $20 \mathrm{~cm}$ were determined following Shidan Bao's (2005) method and the following results were obtained: total C, $31.3 \mathrm{~g} \mathrm{~kg}^{-1}$; total N, $3.94 \mathrm{~g} \mathrm{~kg}^{-1}$; available $\mathrm{N}, 269.7 \mathrm{mg} \mathrm{kg}^{-1}$; available P, $203.6 \mathrm{mg} \mathrm{kg}^{-1}$; available $\mathrm{K}$, $184.4 \mathrm{mg} \mathrm{kg}^{-1} ; \mathrm{pH} 7.20$.

The experimental design consisted of six treatments (three replicates each). Each plot was $7.0 \times 3.0 \mathrm{~m}$ in size. The following biofumigation materials were used in experiments: (1) mustard containing medial glucosinolates (MU), (2) mustard containing high glucosinolates (MHG), (3) mustard containing low glucosinolates (MLG), (4) turnip (TU). These materials were cut into small pieces of less than $2 \mathrm{~cm}$ and were incorporated into the $0-20 \mathrm{~cm}$ depth soil by a rotary machine (garden equipment; $3.5 \mathrm{~kg} \mathrm{~m}^{-2}$ ). Then, the soil was irrigated to ensure that sufficient moisture was present for glucosinolate hydrolysis. Subsequently, the soil was covered with plastic film mulch. Ten days later, the mulch was removed and the soil was thoroughly ploughed. Chemical fumigation (hymexazol (HY), $3 \mathrm{~g} \mathrm{~m}^{-2}$ ) 
and no fumigation (CK) were used as control treatments. Soil samples were collected before the transplantation of cucumber seedlings in June of 2011.

Cucumber seeds under examination were wrapped in gauze and placed in a water bath at $50^{\circ} \mathrm{C}$ for $30 \mathrm{~min}$. The seeds were then incubated at a constant temperature incubator $\left(28^{\circ} \mathrm{C}\right)$ until the radicle length reached $1 \mathrm{~cm}$. The radicles were placed in bowl containing nutrients in horticultural experiment station. When the cucumber seedlings had 3 leaves, they were transplanted into soil and cultured in a greenhouse at $25^{\circ} \mathrm{C}$ in day time and $20^{\circ} \mathrm{C}$ at night.

\section{Glucosinolate concentration analysis in plant roots}

Six roots of $7 \mathrm{~cm}$ in diameter for each biofumigation material (MLG, MU, MHG, and TU) were randomly selected, freeze-dried and then grounded for GSL extraction.

The freeze-dried roots were crushed (100 mesh) and mixed. Dust materials were weighed accurately $(0.50 \mathrm{~g})$, transferred into centrifuge tube $\mathrm{A}$ and $\mathrm{B}$, and extracted with $4 \mathrm{~mL}$ of $70 \%$ methanol $\left(75^{\circ} \mathrm{C}\right)$. Tube B had another $200 \mu \mathrm{l}$ of $5 \mathrm{mmol} \mathrm{L}-1$ sinigrin as an inter-standard. The extracts were heated for $10 \mathrm{~min}$ at $75^{\circ} \mathrm{C}$ in a water bath, followed by adding $1 \mathrm{~mL}$ of $0.4 \mathrm{M}$ acetic barium and centrifuged at $4000 \mathrm{r} / \mathrm{m}$ for $10 \mathrm{~min}$. The supernatants were decanted and pour into $10 \mathrm{ml}$ flask, pellets were re-extracted twice with $3 \mathrm{~mL}$ of $70 \%$ methanol. Supernatants were combined and made up to a total volume of $10 \mathrm{ml} .5 \mathrm{~mL}$ extract was loaded onto acetic acid type anion exchange column of DEAE-SephadexA-25, and allowed to enzymatic $12 \mathrm{~h}$ with $250 \mu \mathrm{l}$ sulfatase. Rinse with $5 \mathrm{ml}$ pure water, mix up eluent and use $0.45 \mu \mathrm{m}$ microporous membrane filtration, sealing, liquid chromatography to be analyzed.

HPLC analysis and quantification: The $10 \mu \mathrm{l}$ sample volume was analyzed in a Merck HPLC system consisting of L7100 gradient pump, L7200 type autosampler, L7455 UV detector set at $229 \mathrm{~nm}$ and a Novapak $\mathrm{Cl} 8$ column (at $30^{\circ} \mathrm{C}$ ). The mobile phase was ultra-pure water and acetonitrile. The flow rate was $1.3 \mathrm{ml} \cdot \mathrm{min}-1$ in a linear gradient from 0 to $20 \%$ acetonitrile during 2 to $34 \mathrm{~min}$ (A pump) and constant $20 \%$ acetonitrile for 6 min (B pump), finally eluted with 100\% acetonitrile (C pump) $10 \mathrm{~min}$ and equilibrated with $0 \mathrm{~B}$ prior to the injection of the next sample.

Use benzyl GSs as an internal standard, according to the retention times and peak areas to determine glucosinolates component qualitative and quantitative. GSs concentration is expressed by containing in several GSs micromoles per gram sample of dry powder ( $\mu \mathrm{mol} / \mathrm{g} \mathrm{DW})$.

\section{DNA extraction and purification}

Soil from each plot was sampled at 9 random locations in each plot two hours before the biofumigation (BB) and ten days after the fumigation (AB). Soil samples from plots were also collected when the cucumber (Cucumis sativus L. Changchunmici) was at seedling (SS), flowering (FS), and maturity (MS) stages. Soil samples were collected from 0 to $20 \mathrm{~cm}$ depth in each plot treatment according to a staggered grid method using a $3.0-\mathrm{cm}$ diameter gauge. All soil samples were stored at $-80^{\circ} \mathrm{C}$ for DNA analysis.

DNA was extracted from $1 \mathrm{~g}$ of frozen soil according to Zhou et al. (1996) method with minor modifications. Soil samples were pretreated with EDTA and PVPP. Because this treatment efficiently removed humic substances, EDTA was used in the extraction of crude DNA. To $1 \mathrm{~g}$ of each soil sample, $3 \mathrm{ml}$ TENP buffer $\left[50 \mathrm{mmol} \mathrm{L}^{-1}\right.$ Tris (pH 8.0), $100 \mathrm{mmol} \mathrm{L}^{-1} \mathrm{NaCl}, 20 \mathrm{mmol} \mathrm{L}^{-1}$ EDTA, and $0.01 \mathrm{~g} \mathrm{ml}^{-1}$ PVPP, $\mathrm{pH} \mathrm{10.0]} \mathrm{was} \mathrm{added,} \mathrm{the} \mathrm{mixture} \mathrm{was}$ shaken, and allowed to stand for $2 \mathrm{~min}$, and repetition of 3 times. Centrifugation at 9,000 rpm for $5 \mathrm{~min}, 3 \mathrm{ml}$ PBS buffer $\left(8 \mathrm{~g} \mathrm{NaCl}, 0.2 \mathrm{~g} \mathrm{KCl}, 1.44 \mathrm{~g} \mathrm{Na}_{2} \mathrm{HPO}_{4}, 0.24 \mathrm{~g}\right.$ $\mathrm{KH}_{2} \mathrm{PO}_{4}$, soluble in $1 \mathrm{~L}$ water, $\mathrm{pH}$ 7.4) was added. And the mixture was repeatedly shaken, and allowed to stand for $2 \mathrm{~min}$, and repetition of 3 times before centrifugation at 9,000 rpm for $5 \mathrm{~min}$.

After pretreating with EDTA and PVPP, the soil sample was mixed with $3 \mathrm{ml}$ of DNA extraction buffer $\left(100 \mathrm{mmol} \mathrm{L}^{-1}\right.$ Tris-HCl, $100 \mathrm{mmol} \mathrm{L}^{-1}$ EDTA, $100 \mathrm{mmol}$ $\mathrm{L}^{-1} \mathrm{Na}_{3} \mathrm{PO}_{4}, 1.5 \mathrm{mmol} \mathrm{L}^{-1} \mathrm{NaCl}, 1 \%$ CTAB, $\mathrm{pH}$ 8.0), $20 \mu \mathrm{l}$ of proteinase $\mathrm{K}\left(20 \mathrm{mg} \mathrm{ml}^{-1}\right)$, and $30 \mu \mathrm{l}$ lysozyme $\left(100 \mathrm{mg} \mathrm{ml}^{-1}\right)$ in centrifuge tubes. To this mixture, $0.5 \mathrm{ml}$ of a $20 \%$ solution of SDS was added and the samples were incubated in a water bath at $65^{\circ} \mathrm{C}$ for $2 \mathrm{~h}$ with gentle endover-end inversions every 15 to $20 \mathrm{~min}$. After centrifuging these samples at 9,000 rpm for $15 \mathrm{~min}$ at room temperature, the supernatants were collected and transferred into new centrifuge tubes. Supernatants from multiple extractions performed for the same sample were combined, mixed with an equal volume of phenol-chloroform-isopentyl alcohol (25:24:1, vol/vol) mixture, and centrifuged at 9,000 rpm for $15 \mathrm{~min}$. The supernatants were collected into new centrifuge tubes, mixed with an equal volume of chloroform-isopentyl alcohol (24:1, vol/vol) mixture, and centrifuged at 9,000 $\mathrm{rpm}$ for $15 \mathrm{~min}$. The aqueous phase was recovered by centrifugation and precipitated with 0.6 volume of isopropanol at room temperature for $1 \mathrm{~h}$. The pellet of crude nucleic acids was collected by centrifuging this mixture at 12,000 rpm for $20 \mathrm{~min}$ at room temperature. The nucleic acid pellet was subsequently washed with cold $70 \%$ ethanol, centrifuged at 12,000 rpm for $2 \mathrm{~min}$, and resuspended in sterile deionized water to a final volume of $50 \mu$ l. 
The crude DNA thus extracted was diluted in $100 \mu \mathrm{l}$ of TE buffer (100 mmol L-1 Tris-HCl, $100 \mathrm{mmol} \mathrm{L}^{-1}$ EDTA, PH 8.0) and purified with the help of the DNA gel Kit from haigene according to the manufacturer's instructions. The purified DNA was stored at $-20^{\circ} \mathrm{C}$ until use.

\section{Polymerase chain reaction}

The V3 region of the bacterial $16 \mathrm{~S}$ rRNA gene was amplified according to the method described by Muyzer et al. (1993) using the primer pair F388-GC/ R518 [Table.1, (HuaDa Genetic technology, Beijing, China)]. The PCR reaction system contained $0.5 \mu$ l each of forward and reverse primers $\left(10 \mathrm{pmol} \mu \mathrm{l}^{-1}\right), 1 \mu \mathrm{l}$ of DNA template, $2 \mu$ l of dNTP, $0.25 \mu l$ of Taq polymerse, $2.5 \mu \mathrm{l} 10 \times$ PCR buffer, and $18.25 \mu$ l sterile deionized water. PCR amplification was performed on a PCR System 9700 (Foster, CA, USA) instrument. The thermal cycling conditions were the following: $94^{\circ} \mathrm{C}$ for $5 \mathrm{~min}$, 30 cycles of denaturation at $94^{\circ} \mathrm{C}$ for $1 \mathrm{~min}$, annealing at $61^{\circ} \mathrm{C}$ for $1 \mathrm{~min}$, and extension at $72^{\circ} \mathrm{C}$ for $1 \mathrm{~min}$ with a final extension at $72^{\circ} \mathrm{C}$ for $10 \mathrm{~min}$. The presence of PCR products was confirmed by electrophoresis on $1.5 \%$ agarose gels, which were stained with EB buffer and photographed.

When analyzing the samples for fungi, the primer set NS7GC/NS8 was used according to the method described by White et al. (1990) and an annealing temperature of $61^{\circ} \mathrm{C}$ was applied [Table.1, (HuaDa Genetic technology, Beijing, China)]. Each $25 \mu$ l of PCR mixture contained 0.5 $\mu l$ each primer, $1 \mu l$ of DNA template, $2 \mu l$ of dNTP, 0.25 $\mu \mathrm{l}$ of Taq polymerse, $2.5 \mu \mathrm{l} 10 \times$ PCR buffer, and $18.25 \mu \mathrm{l}$ sterile deionized water. PCR amplification was performed under the following conditions: $94^{\circ} \mathrm{C}$ for $5 \mathrm{~min}$, followed by 30 cycles of denaturation at $94^{\circ} \mathrm{C}$ for $1 \mathrm{~min}$, annealing at $61^{\circ} \mathrm{C}$ for $1 \mathrm{~min}$, and extension at $72^{\circ} \mathrm{C}$ for $1 \mathrm{~min}$, with a single final step of elongation at $72^{\circ} \mathrm{C}$ for $10 \mathrm{~min}$. The
PCR products were separated by electrophoresis on 1.5\% agarose gel, stained with EB buffer, and photographed using a digital camera.

\section{Denaturing gradient gel electrophoresis}

Denaturing gradient gel electrophoresis (DGGE) was employed to resolve the PCR products on $8 \%$ polyacrylamide gels with a denaturing gradient ranging of $40 \%-65 \%$ and $25 \%-55 \%$ for bacteria and fungi, respectively, where $100 \%$ denaturant was defined as a mixture of $7 \mathrm{M}$ urea and $40 \%$ deionized formamide (Liang et al., 2008). A maker lane containing standard DNA mixtures were used. DGGE analysis was used to perform by a DCode Universal Mutation Detection System (Bio-Rad, USA), and run in a 1 $\times$ TAE buffer for $14 \mathrm{~h}$ under constant conditions of $60^{\circ} \mathrm{C}$ and $70 \mathrm{~V}$. DNA sample volume per well was $30 \mathrm{ul}$. After the electrophoresis, the gel was silver-stained using the method described by Bassam et al. (1991). DGGE profiles were immediately photographed on a white light box.

\section{Analysis of the DGGE banding patterns}

The bands in DGGE profile were analyzed using the Quantity One software (version 4.6.2, Bio-Rad), which automatically determined the position and intensity of each band. The density value of each band was divided by the average band density of the lane to minimize the effect of variations in the amount of DNA loaded (Garland and Mills, 1991). Bands were considered common if they migrated to the same distance in the gel (Wallis et al., 2010). Each band was considered to represent a single operational taxonomic unit (OTU). Normalized data were used for cluster analysis. These analyses were performed using the SPSS 19.0 software. The diversity of soil microbial community was evaluated by the Shannon-Weaver index of general diversity, H (Shannon and Weaver, 1963). $\mathrm{H}$ was calculated from the peak height for the different bacterial groups using the following equation: $\mathrm{H}=-\Sigma$ $\left(n_{i} / N\right) \log \left(n_{i} / N\right)$, where $n_{i}$ is the height of the peak and $N$

Table 1: Total glucosinolate and various types of glucosinolates concentrations(umol $\mathbf{~ g}^{-1} \mathrm{DW}$ )in different dry biofumigation materials roots

\begin{tabular}{lcccc}
\hline Glucosinolate & MLG & MU & MHG & TU \\
\hline Progoitrin & - & - & - & $6.41 \pm 0.014^{\mathrm{a}}$ \\
Gluconapoleiferin & $0.07 \pm 0.003^{\mathrm{b}}$ & $0.07 \pm 0.001^{\mathrm{b}}$ & $0.06 \pm 0.003^{\mathrm{b}}$ & $1.76 \pm 0.115^{\mathrm{a}}$ \\
Glucoalyssin & $0.04 \pm 0.003^{\mathrm{c}}$ & $0.12 \pm 0.008^{\mathrm{b}}$ & $0.05 \pm 0.002^{\mathrm{c}}$ & $0.29 \pm 0.041^{\mathrm{a}}$ \\
Gluconapin & $21.05 \pm 0.355^{\mathrm{c}}$ & $26.05 \pm 0.561^{\mathrm{b}}$ & $32.7 \pm 0.000^{\mathrm{a}}$ & $1.78 \pm 0.036^{\mathrm{d}}$ \\
Glucobrassicanapin & $4.47 \pm 0^{-174 b}$ & $4.18 \pm 0.083^{\mathrm{b}}$ & $5.19 \pm 0.000^{\mathrm{a}}$ & $4.03 \pm 0.195^{\mathrm{b}}$ \\
Glucoerucin & - & - & - & $0.15 \pm 0.087^{\mathrm{a}}$ \\
Glucobrassicin & $0.13 \pm 0.009^{\mathrm{b}}$ & $0.54 \pm 0.025^{\mathrm{a}}$ & $0.17 \pm 0.000^{\mathrm{b}}$ & $0.17 \pm 0.100^{\mathrm{b}}$ \\
4-methoxyglucobrassicin & $0.14 \pm 0.003^{\mathrm{c}}$ & $0.17 \pm 0.004^{\mathrm{a}}$ & $0.16 \pm 0.000^{\mathrm{b}}$ & $0.12 \pm 0.001^{\mathrm{d}}$ \\
4-hytroxyglucobrassicin & - & - & - & $0.26 \pm 0.035^{\mathrm{a}}$ \\
Neoglucobrassicin & - & $0.33 \pm 0.015^{\mathrm{b}}$ & $0.15 \pm 0.003^{\mathrm{c}}$ & $-0.54 \pm 0.065^{\mathrm{a}}$ \\
Gluconasturtiin & $0.25 \pm 0.004^{\mathrm{bc}}$ & - & - & $6.56 \pm 0.080^{\mathrm{a}}$ \\
Ttotal & $26.15 \pm 0.328^{\mathrm{c}}$ & $31.1 \pm 0.701^{\mathrm{b}}$ & $38.49 \pm 0.003^{\mathrm{a}}$ & $22.09 \pm 0.000^{\mathrm{d}}$ \\
\hline
\end{tabular}

Values in the same column, followed by the same letter, do not significantly differ $(P \leq 0.05$, SPSS). 
is the sum of all peak heights in the densitometric curve. Statistical analysis was performed using the general linear model (GLM) procedure of the SPSS 19.0 software (SPSS Institute Inc., IBM, USA).

The Quantity one software (version 4.6.2, Bio-Rad) was used in the Cluster analysis of bacterial and fungal communities, which assessed the similarity between the different soil microbial species and classified the edaphon to different clusters.

\section{Inhibition of cucumber Fusarium wilt Experiment design}

A pot experiment was carried out to study the effect of biofumigation on cucumber Fusarium wilt. The soil used in this study was collected from a continuously cropped cucumber greenhouse in which the temperature was $18^{\circ} \mathrm{C}-32^{\circ} \mathrm{C}$, and the relative humidity was $60 \%-90 \%$. The soil was filtered through a $2-\mathrm{mm}$ sieve and sterilized prior to use. Each pot was filled with $2 \mathrm{~kg}$ soil. Fresh mustard plants containing high glucosinolate, mustard plants containing low glucosinolate, and spinach without glucosinolate were cut into small pieces and incorporated into the soil at a rate of $3.5 \mathrm{~kg} \mathrm{~m}^{-2}$. Chemically fumigated (hymexazol) soil and non-fumigated continuously cropped soil served as control treatments. One cucumber seedling was inoculated with Fusarium oxysporum and transplanted into each pot. There were five treatments in total, and each treatment had eight replicates.

\section{Inoculating cucumber Fusarium oxysporum f. sp. cucumerinum Owen}

The radicle method was used for the inoculation of cucumber with the Fusarium wilt pathogen. Fusarium oxysporum $f$. sp. cucumerinum Owen was obtained from the Pathology Laboratory of Northeast Agricultural University. The isolated Fusarium oxysporum $f$. sp. cucumerinum Owen had been previously tested for pathogenicity. Potato dextrose agar medium inoculated with Fusarium wilt pathogen was incubated for $10 \mathrm{~d}$ at $30^{\circ} \mathrm{C}$ and then filtered with double gauze to remove the hypha. The filtrate was centrifuged at 4,000 rpm for $1 \mathrm{~min}$ at a relative centrifugal force value of $5366 \mathrm{~g}$. The supernatant was discarded, and the centrifugate was diluted with sterile distilled water to a concentration of $2 \times 10^{6}$ spores $\mathrm{ml}^{-1}$. The cucumber seeds were wrapped in gauze, incubated in a water bath at $50^{\circ} \mathrm{C}$ for $30 \mathrm{~min}$, and germination was accelerated at $28^{\circ} \mathrm{C}$ in a constant temperature incubator to a radicle length of approximately $1 \mathrm{~cm}$. The radicles were soaked in the spore suspension for 30 min and transferred into pots with different fumigation treatments. The cucumber seedlings were cultivated for $30 \mathrm{~d}$ in a greenhouse at a temperature of $18^{\circ} \mathrm{C}-32^{\circ} \mathrm{C}$ and a relative humidity of $60 \%-90 \%$.

\section{Fusarium oxysporum density in soil}

Colony forming units (CFU) were determined to analyze the Fusarium wilt pathogen density in the soil. Soil from each treatment group was collected and stored refrigerated at $4^{\circ} \mathrm{C}$ for less than one week before counting the colonies.

We weighed $1.00 \mathrm{~g}$ soil, added it into $100 \mathrm{ml}$ sterilized water and shaken for $20 \mathrm{~s}$. From this suspension, $1 \mathrm{ml}$ was drawn and added to $9 \mathrm{ml}$ sterile water. An aliquot of $0.4 \mathrm{ml}$ of this soil suspension was plated evenly on the surface of pentachloronitrobenzene selective culture-medium $\left(1 \mathrm{~g} \mathrm{~L}^{-1} \mathrm{KH}_{2} \mathrm{PO}_{4}, 5 \mathrm{~g} \mathrm{~L}^{-1}\right.$ peptone, $0.5 \mathrm{~g} \mathrm{~L}^{-1}, \mathrm{MgSO}_{4} \cdot 7 \mathrm{H}_{2} \mathrm{O}$, $20.0 \mathrm{~g} \mathrm{~L}^{-1}$ agar, $300.0 \mathrm{mg} \mathrm{L}^{-1}$ streptomycin, $1.0 \mathrm{~g} \mathrm{~L}^{-1} 75 \%$ pentachloronitrobenzene wettable powder) and cultured for seven days at $28^{\circ} \mathrm{C}$. Following this, the colonies were counted. Each treatment was performed in quadruplicates.

\section{Growth index}

A ruler was used to measure the height of cucumber seedlings. Vernier calipers were used to measure the stem diameter. The cucumber seedlings were harvested and dried at $70^{\circ} \mathrm{C}$ to obtain a constant weight.

\section{STATISTICAL ANALYSIS}

All statistical analyses were performed using SPSS statistical software (IBM SPSS Statistics 19). Differences at the $\mathrm{P} \leq 0.05$ level were considered to be statistically significant.

\section{RESULTS}

\section{Glucosinolate concentrations in different fumigation materials}

Seven glucosinolates (gluconapoleiferin, glucoalyssin, gluconapin, glucobrassicanapin, glucobrassicin, 4-methoxyglucobrassicin and neoglucobrassicin) were identified in three mustard fumigation materials of which gluconapin was the main glucosinolate and accounted for $80 \%-85 \%$ of the total (Table.2). In addition to the seven glucosinolates contained in mustard, turnip also contained four glucosinolates, of which progoitrin and gluconasturtiin were the main glucosinolates and accounted for $29 \%$ and $28 \%$ of the total, respectively.

\section{Dynamic change in soil bacterial diversity assessed by PCR-DGGE}

The bacterial diversity in the soil samples collected at different cucumber developmental stages was evaluated by DGGE analysis of the amplified partial 16S rRNA genes. The number of bands in the DGGE profiles indicated number of OTUs detected, and the band intensity indicated the population density of each OTU. In the DGGE profile, the bands A1, A2, and A4 were common and were of high density at all sampling times and treatments (Fig. 1). 
Table 2: Primer sequences used for amplifying nucleic acids isolated from bacteria and fungi

\begin{tabular}{lll} 
& Primer & Sequence \\
\hline Bacteria & F338-GC & 5'-CGCCCGCCGCGCGCGGCGGGCGGGGCGGGG GCCGGGGGGCCTACGGGAGGCAGCAG-3' \\
& R518 & 5'-ATTACCGCGGCTGCTGG-3' \\
Fungi & NS7-GC & 5'-CGCCCGCCGCGCCCCGCGCCCGGCCCGCCG CCCCCGCCCCGAGGCAATAACAGGTCTG-3' \\
& NS8 & 5'-TCCGCAGGTTCACCTACGGA-3' \\
\hline
\end{tabular}

When analyzing the samples for bacterial, the primer set F388-GC/R518 was used according to the method described by Muyzer et al. (1993), When analyzing the samples for fungi, the primer set NS7-GC/NS8 was used according to the method described by White et al. (1990)

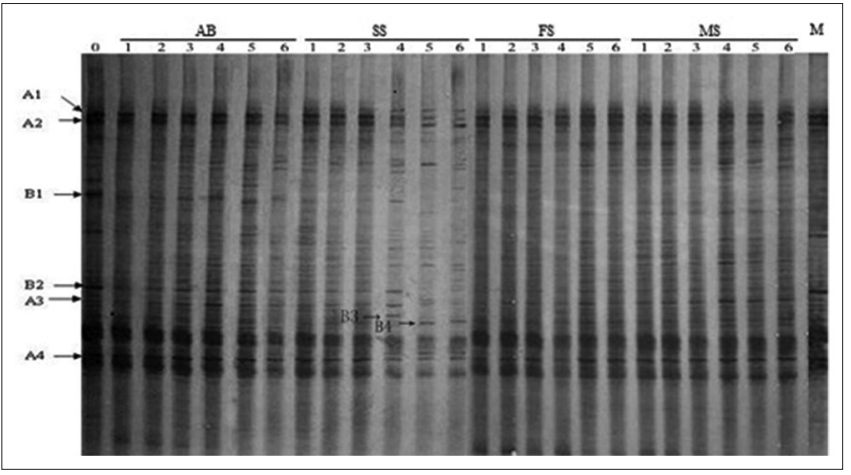

Fig 1. DGGE profiles of bacterial communities in cucumber soil. The numbers $0,1,2,3,4,5$, and 6 above the line indicate the following experimental treatments: Before biofumigation (BB); control (CK); hymexazol (HY); mustard (MU); mustard containing low glucosinolates (MLG); mustard containing high glucosinolates(MHG); and turnip (TU). $A B$ = between the end of biofumigation material incorporation and before the transplantation of cucumber seedlings; $\mathrm{SS}=$ seedling stage; FS = flowering stage; FB = maturity stage.

There were significant differences in the positions or the intensities of some bands. The B1 and B2 bands from samples collected from the soil that were not fumigated were of high intensity. These bands became weak after fumigation and at the flowering and maturity stages. In contrast, band A3 was weak before fumigation and was relatively strong at the flowering stage. In MLG treatments, band B3 showed higher intensity at the seedling stage. In MHG and TU treatments, the B4 band was of a higher intensity at the seedling stage.

The diversity indices calculated from the DGGE band patterns are presented in Table. 3. The Shannon-Weaver index of diversity for bacterial communities in MHGtreated soil (3.49, the highest diversity) was significantly higher than $(\mathrm{P}<0.05)$ that found in other treatment conditions. There was no significant difference $(\mathrm{P}>0.05)$ between the MU and MLG treatments. The Shannon diversity indices were lower in MU (3.44), TU (3.24), and HY (3.12) treatments.

The uniqueness of the DGGE patterns indicated that each sample had a bacterial community. Cluster analysis of PCR amplicons demonstrated that the profiles of these bacterial communities were clustered into three groups (Fig. 2). Group I contained only the HY treatment. Group II
Table 3: Shannon-Weaver index of soil bacteria and fungi at cucumber flower stage following various fumigation treatments

\begin{tabular}{lcc}
\hline Treatments & \multicolumn{2}{c}{$\begin{array}{c}\text { Shannon-Weaver index of } \\
\text { diversity }(\mathbf{H})\end{array}$} \\
\cline { 2 - 3 } & Bacteria & Fungi \\
\hline BB & 3.08 & 2.35 \\
CK & 3.08 & 2.38 \\
HY & 3.12 & 2.44 \\
MU & 3.44 & 2.42 \\
MLG & 3.45 & 2.42 \\
MHG & 3.49 & 2.74 \\
TU & 3.24 & 2.29 \\
\hline
\end{tabular}

Values in the same column, followed by the same letter, do not significantly differ ( $P \leq 0.05$, SPSS).

included the $\mathrm{BB}$ and $\mathrm{CK}$ treatments. The MHG, MLG, TU, and MU treatments were clustered into group III.

\section{Dynamic change in soil fungal diversity assessed by PCR-DGGE}

The analysis of DGGE profiles showed variations in the intensity and number of bands among the soil samples (Fig. 3). The DGGE fingerprints were complex, with the number of bands detected in the samples varying between 15 and 19. The bands A1 and A2, which were of high intensity during cucumber growth periods, were present in all samples. When fungi from soil samples under various biofumigation treatments were analyzed, the number of bands and their position were found to be different. For example, in the MU, MHG, and TU treatments, the band B1, which was not present before fumigation, showed a higher intensity at the seedling stage. The band B2 was stronger at the maturity stage than at other cucumber growth periods. In MHG treatment, the band C1 showed a higher intensity at the seedling stage. At the flowering stage, the intensity of the band $\mathrm{C} 2$ was higher in the TU treatment than in the other biofumigation treatments.

The Shannon-Weaver index of diversity for fungal communities was determined from the DGGE banding patterns. The Shannon diversity indices thus determined that the different soil treatment conditions were significantly different (Table. 3). Among all of treatments, the diversity index of the communities in the MHG-treated soil (2.74) was the highest $(\mathrm{P}<0.05)$ and that of the communities in TU-treated soil was the lowest. There was no significant 
Table 4: Influence of fumigation materials on cucumber seedling growth indicators and Fusarium wilt disease index at seeding stage

\begin{tabular}{lcccc}
\hline Treatments & Dry matter plant $(\mathbf{g})$ & $\begin{array}{c}\text { Plant height } \\
(\mathbf{c m})\end{array}$ & Stem diameter $(\mathbf{c m})$ & Numbers of fusarium oxysporum $\left(\times 10^{3} \mathbf{c f u} \mathbf{g}^{-1} \mathbf{D W}\right)$ \\
\hline CK & $1.01^{\mathrm{c}} \pm 0.02$ & $18.11^{\mathrm{d}} \pm 0.14$ & $0.40^{\mathrm{c}} \pm 0.03$ & $69.04^{\mathrm{a}} \pm 2.77$ \\
$\mathrm{HY}$ & $3.44^{\mathrm{a}} \pm 0.24$ & $49.06^{\mathrm{a}} \pm 0.11$ & $0.68^{\mathrm{a}} \pm 0.04$ & $16.33^{\mathrm{d}} \pm 0.88$ \\
SP & $2.46^{\mathrm{b}} \pm 0.13$ & $34.78^{\mathrm{c}} \pm 0.23$ & $0.51^{\mathrm{b}} \pm 0.02$ & $58.98^{\mathrm{b}} \pm 2.79$ \\
MLG & $3.42^{\mathrm{a}} \pm 0.04$ & $49.25^{\mathrm{a}} \pm 0.13$ & $0.55^{\mathrm{b}} \pm 0.02$ & $31.15^{\mathrm{c}} \pm 1.65$ \\
MHG & $3.07^{\mathrm{a}} \pm 0.02$ & $40.61^{\mathrm{b}} \pm 0.09$ & $0.59^{\mathrm{ab}} \pm 0.01$ & $25.91^{\mathrm{c}} \pm 0.97$ \\
\hline
\end{tabular}

Values in the same column, followed by the same letter, do not significantly differ ( $\leq 0.05$, SPSS)

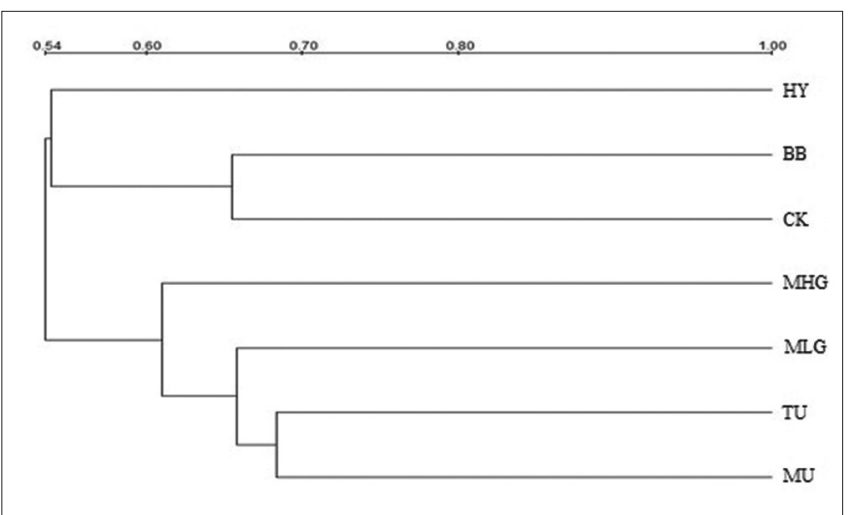

Fig 2. Cluster analysis of bacterial DGGE profiles at cucumber flower stage. $\mathrm{BB}=$ before biofumigation, $\mathrm{CK}=$ control, $\mathrm{HY}=$ hymexazol, $\mathrm{MU}=$ mustard, $\mathrm{MLG}=$ mustard containing low glucosinolates, $\mathrm{MHG}=$ mustard containing high glucosinolates, $\mathrm{TU}=$ turnip.

difference $(\mathrm{P}>0.05)$ between the indices obtained for $\mathrm{HY}$, MU, and MLG treatments.

Cluster analysis of PCR amplification results divided the samples into three clusters, namely clusters I, II and III. Cluster I consisted of the TU treatment, Cluster II consisted of $\mathrm{CK}$ and $\mathrm{BB}$, and Cluster III consisted of MU, MLG, MHG, and HY treatments (Fig. 4), which suggested that the fungus composition between biofumigation and unbiofumiagtion is different.

\section{Inhibition of cucumber fusarium wilt by fumigation materials at the seedling stage}

The incorporation of brassica materials significantly promoted the growth of cucumber seedlings in all fumigation treatments (Table. 4). Compared with samples grown in soil incorporated with spinach, the dry weight of cucumber in soil fumigated with MLG and MHG increased by $40.3 \%$ and $26.3 \%$, respectively. The stem diameter in the MHG treatment was significantly greater than that in other treatments. The abundance of F. oxysporum CFUs in the MHG and HY treatments was significantly lower than that in other treatments. The F. oxysporum CFUs in samples of soil biofumigated by plants were markedly different from that in CK- treated soil sample.

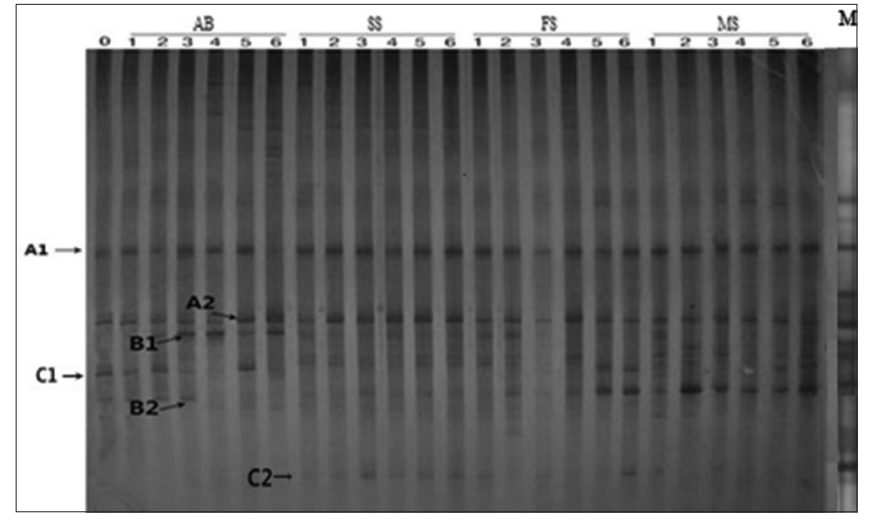

Fig 3. DGGE profiles of fungal communities in cucumber soil. The numbers $0,1,2,3,4,5$, and 6 above the lane indicate the following experimental treatments: Before biofumigation; control; hymexazol; mustard; mustard containing low glucosinolates; mustard containing high glucosinolates; and turnip. $A B=$ between the end of biofumigation material incorporation into soil and before transplantation of cucumber seedlings; $\mathrm{SS}$ = seedling stage; $\mathrm{FS}$ = flowering stage; $\mathrm{FB}$ = maturity stage.

\section{DISCUSSION}

This study investigated the effects of biofumigation (mustard with three levels of glucosinolates and turnip) and chemical fumigation (hymexazol) on cucumber Fusarium wilt and soil microbial community in continuously cropped cucumber soil.

\section{Disease suppression by brassica plant material}

F. oxysporum cannot multiply in many non-host plants that are used as rotation crops or for soil fumigation (Leoni et al., 2013). Biofumigation treatment reduced the Fusarium oxysporum population in the soil, lowered disease incidence in cucumber, and promoted cucumber growth (Table. 4). These results were consistent with that of earlier studies, which found that brassica plant materials were effective in reducing Fusarium wilt (Cohen et al., 2005; Larkin and Griffin, 2007). Additionally, Wang et al. (2014) recently reported that biofumigation successfully controls phytophthora blight. Suppression of Fusarium oxysporum by biofumigation is likely due to the effect of isothiocyanates released following the hydrolysis of glucosinolate present 


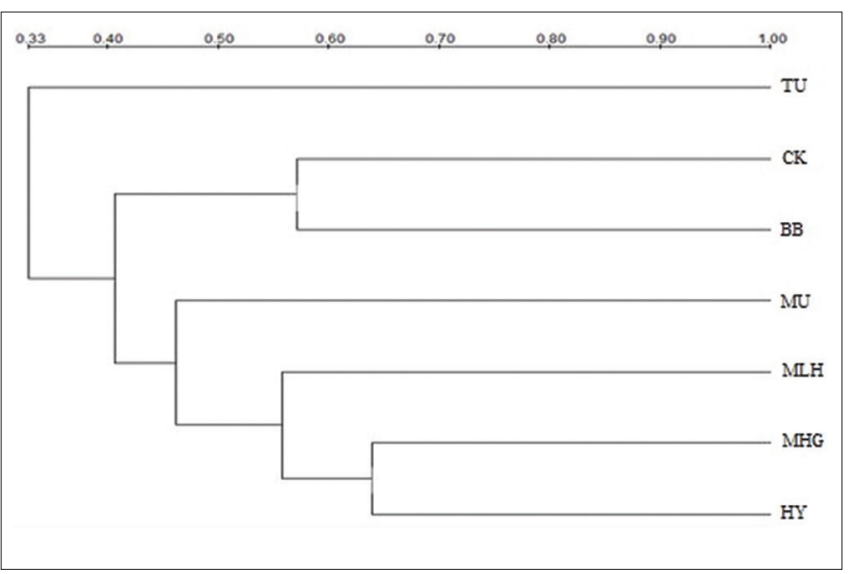

Fig 4. Cluster analysis of fungal DGGE profiles at flowering stage. $\mathrm{BB}=$ before the biofumigation, $\mathrm{CK}=$ control, $\mathrm{HY}=$ hymexazol, $\mathrm{MU}=$ mustard, $\mathrm{MLG}=$ mustard containing low glucosinolates, $\mathrm{MHG}=$ mustard containing high glucosinolates, $\mathrm{TU}=$ turnip.

in brassica crops. Isothiocyanates are toxic for soil-borne pathogens and have been successfully used to reduce soilborne populations of fungal pathogens (Olivier et al., 1999; Muehlchen et al., 1990). Our results showed that the disease index of cucumber fumigated with different brassica crops is different. This is likely due to the differences in the amounts and forms of isothiocyanates released from different brassica crops.

In our pot experiments, a lower amount of Fusarium oxysporum was found in the MHG treatment. Our glucosinolate analysis showed that the Brassica rapa $\mathrm{cv}$ hongyuan used in the MHG treatment contained a high amount of gluconapin (Table.1) the hydrolysis product (3-butenyl isothiocyanate) of which effectively kills soil-borne pathogens (Jang et al., 2010). This likely explains the significantly lower abundance of Fusarium oxysporum found in the MHG-treated soil. Therefore, it appears that glucosinolate content of the brassica crop influences the biofumigation effect to some extent. Owing to the different types of isothiocyanates, the levels of Fusarium wilt suppression were varied. An earlier study by Sarwar and Kirkegaard (1998) reported similar results. The susceptibility of fungi to isothiocyanates contributes to the control of cucumber Fusarium wilt. Brown and Morra (1997) have reported differences in the sensitivity of fungal species to isothiocyanates. Hydrolysis products of glucosinolates or other factors likely play important roles in disease control. Therefore, different Brassica plants control cucumber Fusarium wilt pathogens to different extents.

\section{Soil microbial communities}

DGGE profile analysis revealed an increase in the number and a change in the position of bands after Brassica plants were incorporated into the soil (Fig. 1). For examples, bands B3 and B4 were unique to other treatments (Fig. 1).
Although some bands were present in the profiles of all treatment groups, their intensities varied according to the treatment. For example, the band B2 was weak after biofumigation, whereas the band A2 was strong in the MHG and TU treatment groups at the seeding stage. Additionally, the cluster analysis results showed that the microbial communities in biofumigation treatments differed from those in the HY and CK treatments (Fig. 2). It has been shown that continuous application of 2-phenylethyl isothiocyanate to soil samples leads to noticeable changes in the soil microbial community structure. Taken together, our results suggest that the incorporation of different types of Brassica changed the soil microbial community structures. This finding is in line with those of earlier reports on the incorporation of organic materials into soil (Omirou et al., 2011). Hanna et al. (2009) found variations in the microbial community structure following the incorporation of mustard. In a recent study employing fatty acid methyl ester (FAME) analysis, Omirou et al. (2011) used broccoli plant residues for biofumigation and found that the treatments temporarily altered the composition of microbial communities in the soil. It is possible that changes in the soil microbial community structure led to the observed disease suppression. Several studies have examined the effect of biofumigation with brassica crop residues on soil bacterial communities (Omirou et al., 2011; Cohen et al., 2005).

The Shannon diversity indices of the bacterial and fungi communities that were present in the soil collected after the biofumigation treatments were higher than those of CK and BB treatments (Table. 3). Thus, compared with chemical fumigation and the control, biofumigation increased the soil microbial diversity. This is in line with the results of previous studies that found a rapid increase in bacterial biomass within 5 to 30 days after the incorporation of fresh plant residues (Zelenev et al., 2006; Hanna et al., 2009). These studies identified organic carbon content as the main factor that affects the microbial community structure. In contrast to biofumigation, chemical fumigation with commercial Metham sodium, which releases isothiocyanate into the soil, was found to cause a dramatic reduction in in the activity of the soil microbial community, which persisted for at least 30 days (Omirou et al., 2011). Some studies have concluded that biofumigation does not exert a direct toxic effect on important microbial guilds and that the changes observed reflected a general microbial response to the addition of fresh organic matter into the soil (Omirou et al., 2011). In other words, the brassica materials acted as green manure to alter the physicochemical properties of soil, leading to changes in soil microbial community structures. Wang et al. (2014) reported that biofumigation increased the contents of the total $\mathrm{N}, \mathrm{NO}_{3}{ }^{-} \mathrm{N}$, available $\mathrm{P}$, and available $\mathrm{K}$ in the soil. These authors suggested that the control of pepper disease by biofumigation was mainly linked to the increase 
in soil bacterial diversity rather than the population of soilborne pathogens. Our results also showed that the diversity of bacterial communities increased after biofumigation. However, in contrast to earlier reports, our results suggest that the fungal diversity also increased after biofumigation (Hanna et al., 2009).

The results of cluster analysis of bacterial DGGE profiles showed that the MHG, MLG, TU, and MU treatments were clustered into one group that was different from that of HY and control (Fig. 4). This result suggested that the bacterial community structure of the biofumigated soil was different from that of the chemically fumigated and control soils. The results from the cluster analysis of bacterial DGGE showed that biofumigation with various brassica crops had a similar effect on bacterial community structure and resulted in diversity indices that were higher than those in the HY and CK treatments. Several studies have shown that brassica crops themselves exert a selective influence on the soil microbial communities because brassica plant species, together with other environmental factors, could determine which organisms were active and available to reproduce (Marschner et al., 2004; Innes et al., 2004). Furthermore, incorporation of brassica plants used as biofumigant material increased soil carbon content and tended to influence the soil microbial community structure. The results of the cluster analysis of fungal DGGE profiling showed that the fungi in $\mathrm{CK}$ and $\mathrm{BB}$ treatments belonged to one group, which was in line with the results obtained for bacteria. However, in contrast to that found from the bacterial cluster analysis, the fungi in the MHG and HY treatments appeared in the same group. This result suggested that the influence of different brassica crops on the soil bacterial and fungi structures is different.

In this study, we analyzed the effect of incorporation of brassica plants into soil as biofumigants (LSM, HSM, $\mathrm{MU}$, and TU) on the soil microbial communities without focusing on the changes in specific microbial strains in the treated soil samples. Therefore, additional studies are needed to further elucidate the impacts of biofumigation on the composition of microbial communities.

\section{CONCLUSIONS}

In conclusion, the results of this work indicate that Brassica plants are useful in the control of soil-borne fungal pathogens. Although the pathogen control was not as effective as that by hymexazol, substantial reduction in the abundance of cucumber Fusarium wilt pathogens was observed. Furthermore, incorporation of brassica plants as biofumigant materials increased the content of organic matter in the soil and tended to influence the soil microbial communities, particularly fungi.

\section{ACKONWLEDGMENTS}

This work was financially supported by the Special Found for Agro-scientific Research in the Public Interest, China (201503109) and Heilongjiang Natural Science Foundation, China (C2015016)

\section{AUTHOR'S CONTRIBUTIONS}

XTY, ZCY and RZZ performed most of the experiments, data analysis and original draft preparation. MLB and XRW, $\mathrm{NX}, \mathrm{CYZ}$ contributed to investigation and acquisition of data. CYZ and TTL were involved in sample analysis. SML designed the research and reviewed the manuscript.

\section{REFERENCES}

Angus, J. F., P. A. Gardner, J. A. Kirkegaard and J. M. Desmarchelier. 1994. Biofumigation: Isothiocyanates released from Brassica roots inhibit growth of the take-all fungus. Plant Soil. 162(1): 107-112.

Bassam, B. J., G. Caetano-Anollés and P. M. Gresshoff. 1991. Fast and sensitive silver staining of DNA in polyacrylamide gels. Anal. Biochem. 196(1): 80-83.

Brown, P. D. and M. J. Morra. 1997. Control of soil-borne plant pests using glucosinolate-containing plants. Adv. Agron. 61(C): 167-231.

Buena, A., A. Garcia-Alvarez, M. Diez-Rojo, C. Ros, P. Fernandez and A. Lacasa, A. 2007. Use of pepper crop residues for the control of root-knot nematodes. Bioresour. Technol. 98(15): 2846-2851.

Cohen, M. F., H. Yamasaki and M. Mazzola. 2005. Brassica napus seed meal soil amendment modifies microbial community structure, nitric oxide production and incidence of Rhizoctonia root rot. Soil Biol. Biochem. 37(7): 1215-1227.

Garland, J. L. and A. L. Mills. 1991. Classification and characterization of heterotrophic microbial communities on the basis of patterns of community-level sole-carbon-source utilization. Appl. Environ. Microbiol. 57(8): 2351-2359.

Giotis, C., E. Markelou, A. Theodoropoulou, E. Toufexi, R. Hodson, P. Shotton, R. Shiel, J. Cooper, and C. Leifert. 2009. Effect of soil amendments and biological control agents (BCAs) on soilborne root diseases caused by Pyrenochaeta lycopersici and Verticillium albo-atrum in organic greenhouse tomato production systems. Eur. J. Plant Pathol. 123(4): 387-400.

Hanna, F., E. H. Veronique, F. Celine, G. Nadine, F. Leon, F. Vincent, M. Francoise, and S. Christian. 2009. Cause and duration of mustard incorporation effects on soil-borne plant pathogenic fungi. Soil Biol. Biochem. 41(10): 2075-2084.

Innes, L., P. J. Hobbs, and R. D. Bardgett. 2004. The impacts of individual plant species on rhizosphere microbial communities in soils of different fertility. Biol. Fertil. Soils. 40(1): 7-13.

Jang, M., E. Hong and G. H. Kim. 2010. Evaluation of antibacterial activity of 3-butenyl, 4-pentenyl, 2-phenylethyl, and benzyl isothiocyanate in Brassica vegetables. J. Food Sci. 75(7): 412-416.

Kirkegaard, J. A. 2006. Biofumigation and enhanced biodegradation: Opportunity and challenge in soilborne pest and disease management. Crit. Rev. Plant Sci. 25(3): 235-265.

Larkin, R.P. and T. S. Griffin. 2007. Control of soilborne potato 
diseases using Brassica green manures. Crop Protect. 26(7): 1067-1077.

Leoni, C., M. D. Vries, C. J. F. T. Braak, A. H. C. V. Bruggen and W. A. H. Rossing. 2013. Fusarium oxysporum f.sp. cepae dynamics: In-plant multiplication and crop sequence simulations. Eur. J. Plant Pathol. 137(3): 545-561.

Li, M., S. Li, Z. Miao, R. Guo, and Z. Zhao. 2006. Biofumigation for management of soilborne plant diseases. Chin. J. Biol. Control. 22: 296-302.

Li, S., I. Schonhof, A. Krumbein, L. Li, H. Stützel, and M. Schreiner. 2007. Glucosinolate concentration in turnip (Brassica rapa ssp. Rapifera L.) Roots as affected by nitrogen and sulfur supply. J. Agric. Food Chem. 55(21): 8452-8457.

Liang, Z., R. A. Drijber, D. J. Lee, I. M. Dwiekat, S. D. Harris, and D. A. Wedin. 2008. A DGGE-cloning method to characterize arbuscular mycorrhizal community structure in soil. Soil Biol. Biochem. 40(4): 956-966.

Loenen, M. C. A. V., Y. Turbett, C. E. Mullins, N. E. H. Feilden, M. J. Wilson, C. Leifert, and W. E. Seel. 2003. Low temperatureshort duration steaming of soil kills soil-borne pathogens, nematode pests and weeds. Eur. J. Plant Pathol. 109(9): 9931002.

Marschner, P., D. Crowley and C. H. Yang. 2004. Development of specific rhizosphere bacterial communities in relation to plant species, nutrition and soil type. Plant Soil. 261(1): 199-208.

Muehlchen, A. M., R. E. Rand and J. L. Parke. 1990. Evaluation of crucifer green manures for controlling Aphanomyces root rot of peas. Plant Dis. 74(9): 651-654.

Muyzer, G., E. C. de Waal, andA. G. Uitterlinden. 1993. Profiling of complex microbial populations by denaturing gradient gel electrophoresis analysis of polymerase chain reaction-amplified genes coding for 16S rRNA. Appl. Environ. Microbiol. 59(3): 695-700.

Noble, R. E. Coventry. 2005. Suppression of soil-borne plant diseases with composts: A review. Biocontrol Sci. Technol. 15(1): 3-20.

Ochiai, N., M. L. Powelson, F. J. Crowe, and R. P. Dick. 2008. Green manure effects on soil quality in relation to suppression of Verticillium wilt of potatoes. Biol. Fertil. Soils. 44(8): 1013-1023.

Olivier, C., S. F. Vaughn, E. S. G. Mizubuti and R. Loria. 1999. Variation in allyl isothiocyanate production within Brassica species and correlation with fungicidal activity. J. Chem. Ecol. 25(12): 2687-2701.

Omirou, M., C. Rousidou, F. Bekris, K. K. Papadopoulou, U. Menkissoglou-Spiroudi, C. Ehaliotis, and D. G. Karpouzas. 2011. The impact of biofumigation and chemical fumigation methods on the structure and function of the soil microbial community. Microb. Ecol. 61(1): 201-213.

Paudel, B. R., L. Carpenter-Boggs and S. Higgins. 2016. Influence of Brassicaceous soil amendments on potentially beneficial and pathogenic soil microorganisms and seedling growth in Douglasfir nurseries. Appl. Soil Ecol. 105: 91-100.

Sarwar, M. and J. A. Kirkegaard. 1998. Biofumigation potential of Brassicas: II. Effect of environment and ontogeny on glucosinolate production and implications for screening. Plant Soil. 201(1): 91-101.

Senechkin, I. V., L. S. V. Overbeek and A. H. C. V. Bruggen. 2014. Greater Fusarium wilt suppression after complex than after simple organic amendments as affected by soil $\mathrm{pH}$, total carbon and ammonia-oxidizing bacteria. Appl. Soil Ecol. 73(1): 148-155.

Shannon, A. E. and W. Weaver. 1963. The Mathematical Theory of Communication. University of Illinois Press, Urbana.

Snapp, S. S., K. U. Date, W. Kirk, K. O’Neil, A. Kremen, and G. Bird. 2007. Root, shoot tissues of Brassica juncea and Cereal secale promote potato health. Plant Soil. 294(1): 55-72.

Van Bruggen, A. H., A. Gamliel, and M. R. Finckh. 2015. Plant disease management in organic farming systems. Pest Manage. Sci. 72(1): 30-44.

van Diepeningen, A. D., O. J. de Vos, V. V. Zelenev, A. M. Semenov and A. H. van Bruggen. 2005. DGGE fragments oscillate with or counter to fluctuations in cultivable bacteria along wheat roots. Microb. Ecol. 50(4): 506-517.

Vaughn, S. F., T. A. Isbell, D. Weisleder, and M. A. Berhow. 2005. Biofumigant compounds released by field pennycress (Thlaspi arvense) seedmeal. J. Chem. Ecol. 31(1): 167-177.

Wallis, P. D., R. J. Haynes, C. H. Hunter, and C. D. Morris. 2010. Effect of land use and management on soil bacterial biodiversity as measured by PCR-DGGE. Appl. Soil Ecol. 46(1): 147-150.

Wang, D., C. Rosen, L. Kinkel, A. Cao, N. Tharayil, and J. Gerik. 2009. Production of methyl sulfide and dimethyl disulfide from soil-incorporated plant materials and implications for controlling soilborne pathogens. Plant Soil. 324(1): 185-197.

Wang, Q., Y. Ma, H. Yang, and Z. Chang. 2014. Effect of biofumigation and chemical fumigation on soil microbial community structure and control of pepper Phytophthora blight. World J. Microbiol. Biotechnol. 30(2): 507-518.

White, T. J., T. D. Bruns, S. B. Lee, J. W. Taylor, M. A. Innis, D. H. Gelfand, and J. J. Sninsky. 1990. Amplification and Direct Sequencing of Fungal Ribosomal RNA Genes for Phylogenetics, Acadamic Press, NewYork.

Zelenev, V. V., B. Ahcvan, P. A. Leffelaar, J. Bloem, and A. M. Semenov. 2006. Oscillating dynamics of bacterial populations and their predators in response to fresh organic matter added to soil: The simulation model 'BACWAVE-WEB'. Soil Biol. Biochem. 38(7): 1690-1711.

Zhou, J., M. A. Bruns and J. M. Tiedje. 1996. DNA recovery from soils of diverse composition. Appl. Environ. Microbiol. 62(2): 316-322. 